\title{
PENGEMBANGAN KOMPETENSI KEPROFESIAN BERKELANJUTAN PENDIDIK ANAK USIA DINI DI KECAMATAN JATEN KABUPATEN KARANGANYAR
}

\author{
Nanik Dwi Nurhayati \\ Pendidikan Kimia Fakultas Keguruan dan Ilmu Pendidikan \\ Universitas Sebelas Maret Surakarta \\ E-mail:nanikdn@uns.ac.id \\ Budi Hastuti \\ Pendidikan Kimia Fakultas Keguruan dan Ilmu Pendidikan \\ Universitas Sebelas Maret Surakarta
}

Article received: 05 Desember 2016 Review process: 21 Februari 2017

Article published: 28 Februari 2017

\begin{abstract}
Abstrak
Penelitian bertujuan mengetahui tingkat kompetensi keprofesian dan upaya pengembangan kompetensi keprofesian Pendidik Anak Usia Dini di Kecamatan Jaten Kabupaten Karanganyar. Penelitian merupakan penelitian kuantitatif deskriptif dengan variabel kompetensi keprofesian pendidik dan responden tenaga pendidik anak usia dini yang tergabung dalam Himpaudi Kecamatan Jaten. Teknik pengumpulan data melalui wawancara, observasi, angket tertutup dan terbuka. Validitas data menggunakan validitas isi. Teknik analisis data menggunakan rumus persentase untuk mengetahui pencapaian setiap komponen. Hasil penelitian menunjukkan tingkat kompetensi keprofesian Pendidik Anak Usia Dini Di Kecamatan Jaten Kabupaten Karanganyar dari aspek kompetensi keprofesian materi dan metode pembelajaran sebesar 84,6\% kategori sangat baik, aspek kompetensi keprofesian kurikulum dan silabus sebesar 88,3\% kategori sangat baik, aspek kompetensi keprofesian pengembangan wawasan etika dan profesi sebesar 74,7\% kategori sangat baik dan upaya pengembangan kompetensi profesional terefektif dilakukan pendidik melalui diklat. Pendidik telah melaksanakan penguasaan materi dan metode pembelajaran sesuai kurikulum 13 dan silabus, mengembangkan wawasan etika keprofesian dan keilmuan sangat baik. Namun masih perlu ditingkatkan aspek melakukan penelitian tindakan kelas dan membuat karya ilmiah yang masih jarang dilakukan pendidik sehingga dapat meningkatkan kompetensi profesionalnya.
\end{abstract}

Kata kunci: kompetensi, pendidik paud, Himpaudi Jaten

\section{A. PENDAHULUAN}

Pendidikan merupakan modal dasar untuk menyiapkan insan yang berkualitas. Menurut UNESCO pendidikan hendaknya dibangun dengan empat pilar, yaitu learning to know, learning to do, learning to be, dan learning to live together. Untuk menciptakan generasi yang berkualitas, pendidikan harus dilakukan sejak usia dini dalam hal ini melalui Pendidikan Anak Usia Dini (PAUD). 
Kesadaran masyarakat tentang pendidikan semakin tinggi, karena peranan pendidikan sangat penting bagi manusia. Lembaga PAUD bermunculan dan semakin berkembang menunjukkan peningkatan kesadaran orang tua memberikan pendidikan anak sejak dini yang diimbangi dengan pelayanan kualitas untuk meningkatkan mutu pendidikan.

Kompetensi profesional guru menurut pasal 10 UU nomor 14 Tahun 2005 tentang Guru dan Dosen, bahwa guru memiliki empat kompetensi sebagai pendidik yaitu kompetensi pedagogik, kompetensi kepribadian, kompetensi profesional, dan kompetansi sosial. Pemerintah berupaya menyediakan tenaga pendidik sesuai kebutuhan yang berkualifikasi akademik sesuai bidangnya tercantum dalam Peraturan Menteri Nomor 16 Tahun 2007 tentang Standar Kualifikasi Akademik dan Kompetensi Guru. Kualifikasi akademik Guru PAUD pendidikan minimum diploma empat atau sarjana dalam bidang pendidikan anak usia dini atau psikologi yang diperoleh dari program studi yang terakreditasi. Profesionalitas tenaga pendidik merupakan salah satu faktor penentu keberhasilan pendidikan, oleh karena itu pendidik harus mempunyai kompetensi sesuai bidangnya.

Sesuai Peraturan Pemerintah nomor 74 tahun 2008 tentang Guru pasal 3 ayat 7 bahwa kompetensi profesional meliputi penguasaan materi pelajaran secara luas dan mendalam artinya menguasai bidang studi yang akan diajarkan kepada peserta didik, memiliki pengetahuan fundamental tentang pendidikan, memiliki keterampilan menggunakan serta menerapkan berbagai model serta strategi pembelajaran yang tepat dalam proses pembelajaran. Kemampuan profesional bagi guru PAUD tercantum dalam Permendiknas nomor 52 tahun 2009 tentang standar pendidik yang harus dimiliki antara lain tenaga pendidik mampu menguasai karakteristik peserta didik dari aspek fisik, moral, sosial, kultural, emosional, serta intelektual, mampu mengembangkan kurikulum, mampu menyelenggarakan kegiatan pengembangan yang mendidik bagi peserta didik. Berdasarkan data dari Sapulidi Riset Center (SRC) Januari 2016 terdapat 190.238 lembaga PAUD di seluruh Indonesia dengan jumlah tenaga pendidik 750.769 orang. 


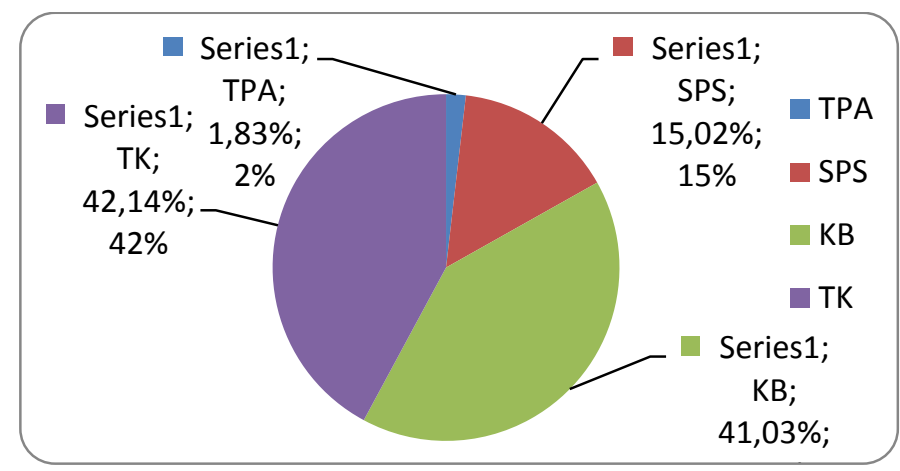

Gambar 1 Data Jumlah PAUD di Indonesia Tahun 2016 menurut SCR

Berdasarkan data tersebut perlu didukung adanya tenaga pendidik yang berkualitas, kreatif dan inovatif dalam pembelajaran. Salah satu landasan dalam pengembangan kurikulum adalah landasan IPTEK, berarti bahwa ilmu pengetahuan dan teknologi secara langsung akan menjadi materi pendidikan.

Kecamatan Jaten merupakan salah satu wilayah di Kabupaten Karanganyar mempunyai 30 lembaga PAUD yang tergabung dalam Himpaudi berdiri sejak tahun 2007. Berdasarkan hasil survey dan wawancara dengan ketua serta pengisian angket kepada pendidik PAUD ada beberapa permasalahan utama yang dihadapi pendidik diantaranya perlu adanya penguasaan materi dan metode pembelajaran, penguasaan kurikulum dan silabus, penguasaan wawasan etika dan pengembangan keprofesian serta perlu pembiasaan melakukan penelitian tindakan kelas yang merupakan refleksi terhadap masalah selama proses pembelajaran.

Adanya penelitian tindakan kelas dapat untuk meningkatkan kegiatan pembelajaran di kelas. Namun penelitian tindakan kelas masih jarang dilakukan oleh guru. Menyikapi berbagai persoalan yang ada perlu dilakukan suatu upaya peningkatan kemampuan profesional guru baik dari diri sendiri maupun lembaga. Peningkatan kemampuan profesional dapat dilalui melalui pengembangan kompetensi profesional yang dilakukan oleh guru.

Pengembangan merupakan suatu tindakan yang dilakukan unyuk meningkatkan mutu tenaga personalia menjadi lebih baik. Tujuan pengembangan kemampuan profesional untuk membantu guru dalam memperluas pengetahuan, meningkatkan keterampilan mengajar, dan menumbuhkan sikap profesional dalam mengelola kegiatan belajar mengajar.

Peningkatan kompetensi profesional pendidik dapat dilakukan secara kelompok maupun secara individual, yang dapat dilakukan oleh pengawas, kepala sekolah maupun antar guru. Secara kelompok peningkatan kompetensi dilakukan dengan adanya pengembangan 
kompetensi profesional dapat diselenggarakan melalui semiar atau workshop, pelatihan atau diklat, maupun lembaga organisasi profesi yaitu melalui Himpaudi, kegiatan Kelompok Kerja Guru (KKG) dan kelompok gugus. Peningkatan kemampuan profesional secara internal dilakukan dengan cara pembinaan motivasi kerja kepada guru dalam bentuk pembinaan moral kerja yaitu memberikan dorongan guru untuk meningkatkan kemampuan profesionalnya, melakukan diskusi antar teman sejawat dan peningkatan kemampuan profesionalnya dengan belajar mandiri melalui berbagai literatur pendidikan ataupun melanjutkan studi pendidikan yang sesuai dengan profesi pendidik.

Kualifikasi akademik studi lanjut bidang Pendidikan Anak Usia Dini menjadi pemacu bagi pendidik untuk meningkatkan kemampuan profesional, karena kebanyakan pendidik Paud tidak berijazah PAUD (PG-PAUD) atau Pendidikan Guru Taman Kanak-kanak (PGTK). Studi lanjut digunakan untuk memenuhi syarat sertifikasi pendidik, sehingga mendapatkan tunjangan sertifikasi atau profesi yang dapat digunakan untuk menambah dan mengasah kemampuan profesional untuk meningkatkan mutu pendidikan sesuai tujuan nasional. Oleh karena itu perlu dilakukan penelitian Pengembangan Kompetensi Keprofesian Berkelanjutan Pendidik Anak Usia Dini Di Kecamatan Jaten Kabupaten Karanganyar.

\section{B. METODOLOGI PENELITIAN}

Penelitian ini merupakan penelitian deskriptif dengan pendekatan kuantitatif yaitu mendeskripsikan keadaan dilapangan, menganalisis data yang digambarkan dalam persentase artinya mendeskripsikan kompetensi keprofesian bagi pendidik anak usia dini di Kecamatan Jaten Kabupaten Karanganyar dan upaya pengembangan untuk meningkatkan kompetensi keprofesian. Populasi penelitian adalah semua pendidik anak usia dini di lembaga Himpaudi Kecamatan Jaten Kabupaten Karanganyar sejumlah 120 orang yang dilakukan pada bulan Agustus 2016. Dari populasi tersebut diambil sejumlah pendidik sebagai sampel sesuai perhitungan menggunakan rumus Slovin, sehingga ada 75 orang. Variabel penelitian adalah pengembangan kompetensi profesional pendidik anak usia dini yang dilihat dari aspek kompetensi profesional pendidik yaitu penguasaan materi dan metode pembelajaran, penguasaan kurikulum dan silabus, penguasaan wawasan etika dan pengembangan keprofesian.

Teknik pengumpulan data dengan menggunakan teknik cluster proportional random sampling metode wawancara, observasi, angket. Penelitian dilakukan dengan memberikan angket yang berisi sejumlah pertanyaan berdasarkan kisi-kisi instrumen penelitian yaitu angket 
tertutup untuk mengetahui kompetensi profesional pendidik dan upaya pengembangan kompetensi profesional dari segi penguasaan materi dan metode pembelajaran, kurikulum dan silabus pembelajaran dengan memberikan tanda checklist $(\sqrt{ })$ pada kolom jawaban yang tersedia yaitu selalu, sering, kadang- kadang, dan tidak pernah. Sedangkan angket terbuka pendidik diberikan kebebasan untuk memilih upaya pengembangan kompetensi profesional dan memilih salah satu upaya yang dipandang terefektif dan memberikan alasannya. Angket disertai identitas responden untuk menggali informasi. Teknik analisa data yaitu teknik deskriptif kuantitatif dengan menggunakan perhitungan persentase menurut Winarsunu pada variabel kompetensi keprofesian. Yang digunakan untuk mengetahui kompetensi keprofesian tenaga pendidik, upaya pengembangan yang dilakukan dan upaya pengembangan kompetensi keprofesian terefektif.

\section{PEMBAHASAN}

Kualifikasi Akademik pendidik PAUD/TK/RA minimum diploma empat (D-IV) atau sarjana (S1) dalam bidang pendidikan anak usia dini atau psikologi dari program studi terakreditasi bertujuan agar pendidik memiliki pengetahuan sesuai bidang yang diajarkan kepada peserta didik Sesuai Peraturan Menteri Nomor 16 Tahun 2007 tentang Standar Kualifikasi Akademik dan Kompetensi Guru.

Tabel 1 Kualifikasi Pendidikan Pendidik Anak Usia Dini di Kec. Jaten Kab. Karanganyar

\begin{tabular}{lccccc}
\hline \multirow{2}{*}{ Responden } & \multicolumn{5}{c}{ Pendidikan } \\
& SMA & D1-D3 & S1 & S2 & Jumlah \\
\hline Tenaga Pendidik & 48 & 18 & 49 & 5 & 120 \\
Persentase & 40 & 15 & 41 & 4 & 100 \\
\hline
\end{tabular}

Kualifikasi akademik pendidik anak usia dini dapat dilihat pada diagram lingkaran gambar 2 berikut. 


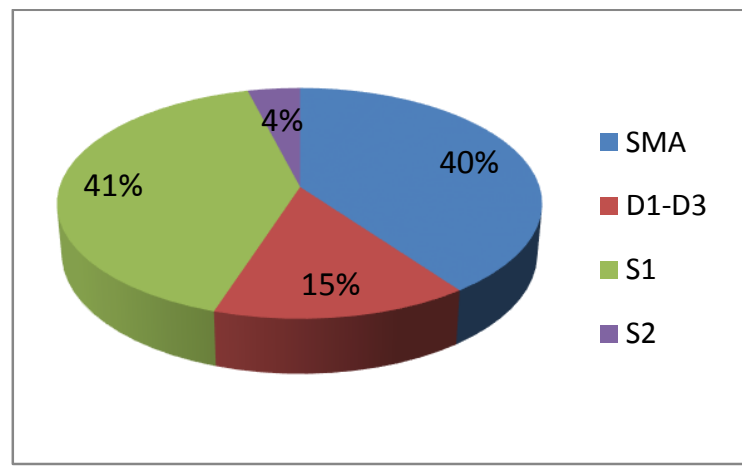

Gambar 2 Diagram Kualifikasi Akademik Pendidik Anak Usia Dini

Kompetensi keprofesian pendidik dapat dilihat dari aspek penguasaan materi dan metode pembelajaran, penguasaan kurikulum/silabus, serta penguasaan wawasan etika dan pengembangan profesi. Dari ketiga aspek tersebut akan dilihat dari segi kompetensi profesional yang sudah dimiliki, upaya pengembangan kompetensi profesional yang terefektif untuk dilakukan beserta alasannya. Kompetensi keprofesian penguasaan materi dan metode pembelajaran di uraikan dalam 10 indikator dilihat pada tabel di bawah.

Tabel 2 Kompetensi Keprofesian Pendidik Anak Usia Dini berdasarkan Penguasaan Materi dan Metode Pembelajaran

\begin{tabular}{|c|c|c|c|}
\hline No & Indikator & Persentase $(\%)$ & Kategori \\
\hline 1. & Menguasai karakteristik anak dari aspek fisik & 89,5 & SB \\
\hline 2. & Menguasai karakteristik anak dari aspek moral & 80,2 & B \\
\hline 3. & Menguasai karakteristik anak dari aspek sosial & 84,4 & SB \\
\hline 4. & $\begin{array}{l}\text { Menguasai karakteristik anak dari aspek } \\
\text { emosional }\end{array}$ & 85,3 & SB \\
\hline 5. & $\begin{array}{l}\text { Menguasai karakteristik anak dari aspek } \\
\text { intelektual }\end{array}$ & 87,1 & SB \\
\hline 6. & Menguasai materi pelajaran & 91,6 & SB \\
\hline 7. & Menguasai kompetensi pembelajaran & 85,4 & SB \\
\hline 8. & Menguasai pengembangan materi pembelajaran & 79,2 & B \\
\hline 9. & Menguasai prinsip pembelajaran & 85,8 & SB \\
\hline \multirow[t]{2}{*}{10.} & Menguasai pemanfaatan teknologi informasi & 77,5 & B \\
\hline & Rata-rata & 84,6 & SB \\
\hline
\end{tabular}

Berdasarkan tabel 2 rata-rata pencapaian kompetensi keprofesian pendidik pada penguasaan materi dan metode pembelajaran sebesar $84,6 \%$ kategori sangat baik (SB). Ketercapaian tersebut merupakan upaya pendidik yang selalu berusaha menguasai materi dan 
metode pembelajaran yang sesuai bagi anak didik. Beberapa indikator perlu ditingkatkan diantaranya pemanfaatan teknologi informasi.

Kompetensi keprofesian pendidik anak usia dini berdasarkan penguasaan pengembangan kurikulum dan silabus materi pada pembuatan rencana pembelajaran dapat dilihat pada tabel di bawah.

Tabel 3 Kompetensi Keprofesian Pendidik Anak Usia Dini berdasarkan Penguasaan Kurikulum dan Silabus Materi

\begin{tabular}{clcc}
\hline No & Indikator & Persentase (\%) & Kategori \\
\hline 1. & Menyusun rencana pembelajaran harian & 94,5 & SB \\
2. & Menyusun rencana pembelajaran mingguan & 86,2 & SB \\
3. & Menyusun rencana pembelajaran semester & 84,3 & SB \\
& Rata-rata & 88,3 & SB \\
\hline
\end{tabular}

Berdasarkan tabel 3 rata-rata pencapaian kompetensi keprofesian pendidik pada penguasaan kurikulum dan silabus sebesar $88,3 \%$ kategori sangat baik artinya pendidik telah memahami dan melaksanakan kurikulum dan silabus sangat baik. Aspek tersebut meliputi pembuatan rencana pembelajaran selama satu semester diantaranya rencana kegiatan semester, rencana kegiatan mingguan, dan rencana kegiatan harian. Rencana kegiatan pembelajaran dikemas dalam kegiatan yang mendidik, menyenangkan, bermain sambil belajar sesuai dengan materi pembelajaran sesuai tahapan perkembangan anak baik pelaksanaan di dalam kelas atau di luar kelas.

Kompetensi keprofesian pendidik anak usia dini berdasarkan penguasaan pengembangan wawasan etika dan pengembangan profesi dilihat pada tabel 4 .

Tabel 4 Kompetensi Keprofesian Pendidik Anak Usia Dini berdasarkan Penguasaan Pengembangan Wawasan Etika Dan Pengembangan Profesi

\begin{tabular}{|c|c|c|c|}
\hline No & Indikator & Persentase $(\%)$ & Kategori \\
\hline 1. & Melakukan penelitian tindakan kelas & 35,2 & $\mathrm{~K}$ \\
\hline 2. & Menunjukkan etos kerja dan tanggungjawab tinggi & 89,5 & SB \\
\hline 3. & Menerapkan kode etik pendidik & 87,3 & SB \\
\hline 4. & Menerapkan komunikasi profesi yang baik & 82,7 & SB \\
\hline \multirow[t]{2}{*}{5.} & Memanfaatkan teknologi informasi & 78,6 & $\mathrm{~B}$ \\
\hline & Rata-rata & 74,7 & B \\
\hline
\end{tabular}


Berdasarkan tabel 4 rata-rata pencapaian kompetensi keprofesian pendidik pada penguasaan pengembangan wawasan etika dan pengembangan profesi sebesar $74,7 \%$ dengan kategori sangat baik artinya semua pendidik telah melaksanakan wawasan etika dan pengembangan profesi sangat baik sesuai indikator. Aspek berkategori sangat baik yaitu menunjukkan etos kerja dan tanggung jawab yang tinggi sebagai pendidik, harus senantiasa di kembangkan sehingga dapat menjalankan tugasnya dengan baik yang harus bertanggung jawab terhadap peserta didik. Aspek berkategori kurang yaitu melakukan penelitian tindakan kelas menunjukkan bahwa masih jarang dilakukan pendidik. Penelitian tindakan kelas sangat bermanfaat untuk perbaikan dan meningkatkan pembelajaran keberlanjutan.

Kompetensi keprofesian pendidik anak usia dini berdasarkan penguasaan pengembangan kompetensi profesional dapat dilakukan dengan berbagai macam melalui workshop, diklat, Kelompok Kerja Guru (KKG), diskusi teman sejawat, studi literatur, studi lanjut, dan membuat karya ilmiah dapat dilihat pada tabel di bawah.

Tabel 5

Pengembangan Kompetensi Profesional Pendidik Anak Usia Dini

\begin{tabular}{clcc}
\hline No & \multicolumn{1}{c}{ Indikator } & Persentase (\%) & Jumlah \\
\hline 1. & Workshop & 28 & 21 \\
2. & Diklat & 35 & 26 \\
3. & Kelompok Kerja Guru (KKG) & 15 & 11 \\
4. & Diskusi Teman Sejawat & 10 & 7 \\
5. & Studi Literatur & 6 & 5 \\
6. & Studi Lanjut & 2 & 2 \\
7. & Membuat Karya Ilmiah & 4 & 3 \\
& & 100 & 75 \\
\hline
\end{tabular}

Berdasarkan hasil analisis sebanyak 35\% responden menjawab diklat merupakan upaya pengembangan kompetensi profesional pendidik anak usia dini terefektif yang dilaksanakan pendidi untuk mengembangkan profesinya. Beberapa alasan dikemukakan responden, dengan adanya diklat yang berlangsung selama beberapa hari memberikan waktu belajar yang lebih panjang pada pembahasan kurikulum, silabus akan lebih mendetail, dan sharing dengan narasumber ahli dalam bidangnya. Berkelanjutan pada praktik atau latihan pembuatan rencana pembelajaran semester kurikulum. Melalui diklat pendidik mendapatkan rekan lebih banyak sehingga dapat menambah wawasan, berbagi pengalaman, berlatih berpikir kreatif dan inovatif. 
Kendala yang dihadapi pendidik, kesempatan mengikuti berbagai diklat sangat terbatas hanya perwakilan yang dapat mengikuti. Upaya pengembangan kompetensi profesional bagi pendidik anak usia dini yang dipandang terefektif digambarkan dalam bentuk diagram lingkaran pada Gambar 3.

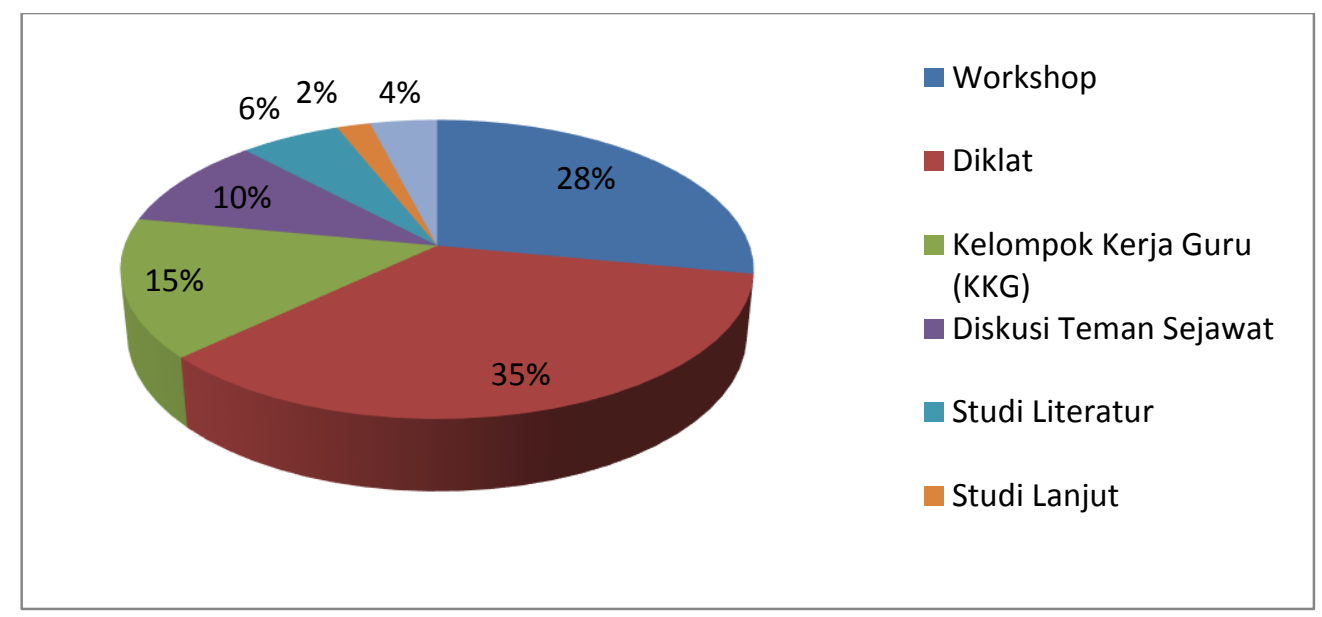

Gambar 3. Upaya Pengembangan Kompetensi Profesional Terefektif

Kompetensi profesional yang kurang dilakukan pendidik yaitu studi literatur dan membuat karya ilmiah, karena tidak memiliki waktu cukup untuk membaca buku dan kurang terbiasa menulis karya ilmiah sehingga perlu menumbuhkan kesadaran membaca buku dan menulis karya ilmiah. Hambatan yang dialami pendidik dalam meningkatkan kompetensi profesional diantaranya minimnya buku referensi yang dimiliki Himpaudi, faktor biaya, waktu, penguasaan Iptek sehingga diperlukan penambahan buku referensi, keringanan biaya studi lanjut, kesempatan mengikuti diklat/workshop/seminar dengan biaya terjangkau.

\section{SIMPULAN}

Berdasarkan data hasil penelitian dapat disimpulkan sebagai berikut:

1. Tingkat kompetensi keprofesian Pendidik Anak Usia Dini Di Kecamatan Jaten Kabupaten Karanganyar dari aspek kompetensi keprofesian materi dan metode pembelajaran sebesar 84,6\% kategori sangat baik, dari aspek kompetensi keprofesian kurikulum dan silabus sebesar 88,3\% kategori sangat baik, dari aspek kompetensi keprofesian pengembangan wawasan etika dan profesi sebesar $74,7 \%$ kategori sangat baik.

2. Upaya pengembangan kompetensi profesional terefektif yang paling banyak dilakukan pendidik melalui diklat karena pendidik mendapatkan lebih banyak wawasan, pengalaman, 
dapat berlatih berpikir kreatif dan inovatif. Kompetensi yang perlu ditingkatkan yaitu aspek melakukan penelitian tindakan kelas dan membuat karya ilmiah yang masih jarang dilakukan pendidik sehingga dapat meningkatkan kompetensi profesionalnya.

\section{DAFTAR PUSTAKA}

Andita, F. (2013). Upaya Pengembangan Profesional Guru Taman Kanak-Kanak di Kecamatan Bantul. Skripsi. Universitas Negeri Yogjakarta.

Arikunto. S. (2006). Prosedur Penelitian Suatu Pendekatan Praktek. Rineka Cipta. Jakarta. Asmani. Ma'mur, J.(2009). Manajemen Strategi Pendidikan Anak Usia Dini. Yogyakarta.

Depdiknas. (2007). Kerangka Dasar Kurikulum Pendidikan Anak Usia Dini. Universitas Negeri Jakarta. Jakarta.

Depdiknas. (2007). Kurikulum Pendidikan Taman Kanak-Kanak Dan Pedoman Penyusunan Silabus. BP Cipta Jaya. Jakarta

Dianingsih, I. (2011). Upaya Guru Dalam Meningkatkan Kompetensi di SDN Se-Kecamatan Piyungan Kabupaten Bantul. Skripsi. Universitas Negeri Yogjakarta.

Hamzah, B. (2008). Profesi Kependidikan, Problema, Solusi, dan Reformasi Pendidikan di Indonesia. Bumi Aksara. Jakarta

Ishartiwi. (2009). Manajemen Diri Menuju Profesionalisme Guru. Jurnal Ilmu Pendidikan. XVI:127-128.

Mulyasa. (2012).Standar Kompetensi dan Sertifikasi Guru. Rosdakarya. Bandung.

Rusman. (2011). Model-Model Pembelajaran Mengembangkan Profesionalisme Guru. PT Raja Grafindo Persada. Jakarta

Setyawati, H. (2013). Analisis Pengelolaan Pembelajaran Oleh Guru Paud Di Kecamatan Pontianak Timur. Skripsi. FKIP Universitas Tanjungpura. Kalimantan Timur.

Yufiarti, Chandrawati. (2011). Profesionalitas Guru PAUD. UniversitasTerbuka. Jakarta.

Yuliana. (2009). Konsep Dasar Pendidikan Anak Usia Dini. Indeks. Jakarta.

Yulindrasari, H. (2011). Peningkatan Kompetensi Profesional Guru Paud Non Formal Melalui Pelatihan Paud Berbasis Active Learning Universitas Pendidikan Indonesia.

Yus, A. (2011). Model Pendidikan Anak Usia Dini. Kencana Predana Media Group. Jakarta. 